\title{
KRISHNA CONSCIOUSNESS IN EUROPE: THE WAY FARMING COMMUNITIES BECAME THE FOCAL POINTS OF MARKETING
}

\author{
Krisztina Bence-Kiss ${ }^{1}$, Orsolya Szigeti ${ }^{2}$ \\ ${ }^{1,2}$ Kaposvár University, H-7400, Kaposvár, Guba Sándor u. 40. \\ 1bence.krisztina@ke.hu \\ 22szigeti.orsolya@ke.hu
}

\begin{abstract}
Krishna Consciousness is regarded as one of the most successful new religious movements in terms of marketing in the Western World. The aim of this research was to identify and analyze the marketing strategy the members of the Krishna-conscious community apply in Europe via content analyses, field research observations and in-depth interviews. The marketing mix of services marketing (7P) are often suggested to be applied by religious communities as well, however, this concept has boundaries due to the principles of the religions, which may not be altered for the sake of marketing. The research has shown that in Europe Krishna-conscious communities have overcome this problem by shifting the product from religion to a complex touristic product, which is realized in the form of farming communities, which have become an important rural tourist attraction in some countries. As the comparison of the websites of the different institutions has shown that rural and farming communities are the ones, which focus mainly on attracting people, who are not familiar with Krishna Consciousness yet, while the websites of the other institutions communicate mostly with devotees or people already interested in the religion or its certain aspect (cuisine, education), rural and farming communities were the institutions chosen to be analyzed more closely. The marketers of these tourist attractions are therefore free to make certain modifications in the marketing mix, as its focus is a tourist attraction, not the religion itself; while the transmission of knowledge about the religion happens in the touristic attractions only. Seven European farming communities of six different countries have participated in the research so far, which may be extended to further communities and continents on the future for a more thorough analysis.
\end{abstract}

Keywords: marketing; religious marketing; farming communities; Krishna Consciousness (JEL code: M31)

\section{INTRODUCTION}

Marketing religions has been a subject of debate for decades. According to the researches many people think that churches doing marketing or any form of economic activities undermines the credibility and the sacredness of a religious community (ATTAWAY et al., 1997; MCDANIEL, 1986; MCGRAW et al., 2011). However, in the middle of the 20th century more and more researchers have started to discuss religious markets, where religious communities compete with each other for followers, just like for-profit companies do on the product and service markets. The literature analyzed suggests that most of the researchers agree on the existence of a religious market, where religious groups are the suppliers, while members and potential worshippers are the customers, who interact with each other on the so-called religious marketplace (CORREA et al., 2017; HAGEVI, 2017; IANNACCONE, 2012). There is also a consensus on the fact that religious markets have gone through significant changes in the past approximately fifty years, thanks to the changes in consumer needs and emergence of new religious movements, which boosted the religious market in most parts of the world - however, about whether these changes take a positive or negative effect on religious life and the reputation of churches, the opinions vary (CROCKETT, 2016; EINSTEIN, 2008; WALRATH, 2017).

However, practices show that most of the religious communities have started to apply at least a limited set of 
marketing tools, which urges the development of a model suitable for studying religious marketing. CULLITON (1958) was one of the first ones to study religious marketing using the marketing mix of 4Ps, where the product is not only the salvation and afterlife happiness offered by religions, but also a guidance to life including a set of standards of what is right or wrong. Price in this case may be identified as the rules, which devotees of a religion are required to follow and in most cases the secular pleasures they need to forgo of, while place either as the institutions, where people meet the religion (a church for example), or the place religion takes in the life of people. CULLITON (1958) also enhanced that the elements of the marketing mix - especially in the case of religions - are inseparable and interrelated, since every aspect aims to sell the product (CULLITON, 1958). ABELA (2014) classified religions in the category of social marketing, meaning those forms of marketing activities, where the focus is not on selling a product or service, but on spreading certain ideas, beliefs or worldviews among the public (ABELA, 2014). FINE (1992) also included religions in his book of Marketing the Public Sector, and proposed an expanded marketing model of the 7P's of social marketing, changing three of the original 7Ps: 'people', 'process' and 'physical evidence' are replaced by 'producer', 'purchaser' and 'probing'. The social marketing approach focuses on the intangible part of religion by including the human side of both parties: producer and purchaser. This model raises the attention to the importance of the churches offering religious services and the nature of people potentially receiving it; however, probing or market research is less applicable to religions than the $7 \mathrm{P}$ of service marketing. Another weakness of the social marketing approach is the lack of the focus on physical evidences, which play important role in characterizing religions (e.g. design of churches and sacred items) (FINE, 2009).

Some researchers took a different approach and focused especially on the resemblance of religions to services, services provided by religious organizations; and different product categories as the material and tangible realizations of the services and the religion. They have found that religions do have some common features with services in many aspects, such as being intangible, not measurable, perishable and pretty heterogeneous as well; and if we consider religious services themselves, then we can clearly see that applicability of the services marketing models (HASHIM and HAMZAH, 2014; IYER et al., 2014; SHAW and THOMSON, 2013).

The greatest limitation of the models above however, is that most of their elements, such as product, price or physical evidence are predetermined by the principles of the religion, therefore they may not be altered for the sake of marketing. This implies that marketers of religious groups need to think in different dimensions and alter their marketing tools to be able to reach potential followers successfully. The aim of this paper is to show via the example of the Krishnaconscious communities in Europe how special religions are from marketing perspective; and to introduce the marketing model applied by devotees of Krishna Consciousness in the European countries.

\section{RESEARCH METHODOLOGY}

Research methodology is the process through which researchers want to conduct their research. It displays the way through which these researchers formulate their research problem and objective, plan to careful, systematic collect and analysis required data and present their result obtained during the study period. It helps to find solutions to a question or recognize a particular phenomenon correctly by going beyond personal experience, thought, feelings and opinion (Johnston 2010).

Accordingly, this study was carried out in capital cities of six districts (Rathnapura, Colombo, Gampaha, Kandy, Kurunegala, and Galle) of Sri Lanka. The main cities of these districts were selected purposively for the study due to their potential for the presence of organic markets and organic consumers. Four super markets were randomly selected from each city, and the target group was obtained from 25 customers came out from the super market after buying goods. Questionnaires were filled from the customers who were willing to participate in the survey. Data collection was done at 24 super markets (04 super markets from each city), and the sample size was 600 customers (100 from each city). Data were collected in two stages: First, via an online survey for the pilot study (Study one) using ten consumers in September 2016, and then, a consumer survey using the pre-tested questionnaire (Study two) in the selected six cities from November 2016 to May 2018. In the questionnaire, consumers were asked information related to socio-economic characteristics, awareness level related to organic food, information related to the present situation of buying organic food, WTP for organic food, and challenges in purchasing organic food. In data analysis, socio-economic characteristics, the level of awareness, information related to present situation of buying organic food, WTP for organic food, and challenges in purchasing organic food were analyzed using descriptive statistics (frequency analysis, percentages), while factors affecting consumers' WTP premium price was measured using binary logistic regression analysis. Data analysis was conducted using the SPSS software version 21. Table 1 presents the variables applied in binary logistics regression.

\section{MATERIALS AND METHODS}

During the secondary research the evolution of religious marketing and the theories on religious markets and the market decisions taken were analyzed, then the theory was examined on a living religious marketing example of Krishna Consciousness. In the primary data collection phase a set of qualitative and quantitative methods were applied to get a thorough overview of the research area. This study introduces the qualitative research phase and the identification of the marketing model of Krishna-conscious communities in Europe.

The qualitative research was initiated by a content analysis of the online presence of Krishna Consciousness in the European countries, the first goal of which was to identify in 
which countries of Europe is the religion present and what its most important forms of appearance are. The content analysis was initiated on the central websites of Krishna Consciousness, which contained a thorough list of all the Krishna-conscious institutions in the world - and in Europe The website analysis has shown that the institutions of Krishna Consciousness in every country may be categorized into four different types, which were temples or centers, farming or rural communicate, educational centers and restaurants (ISKCON, 2019, ISKCON Desire Tree, 2019). In the next step the online presence (websites and social media sites) of these institutions were analyzed from marketing perspective. First of all the target audiences of the different platforms were identified, then the main question of the analysis was how much and in which forms the different institutions contribute to promoting the religion to people outside the religious community. This was important to help filtering those tools and institutions, which focus mainly on intra-religious communication and find the ones, which take active part in promotion among the wider public. As the comparison of the websites of the different institutions has shown that rural and farming communities are the ones, which focus mainly on attracting people, who are not familiar with Krishna Consciousness yet, while the websites of the other institutions communicate mostly with devotees or people already interested in the religion or its certain aspect (cuisine, education), rural and farming communities were the institutions chosen to be analyzed more closely.

Currently there are eighteen farming communities registered in Europe; nine of them have responded to the initial enquiry and all have agreed to participate in the further research. Two of the farming communities had population below ten, and since the marketing activities in their countries were not significantly more active than in the ones without rural communities, they were dropped from the sample.

The second phase of the content analysis focused on the website and social media contents of the seven communities participating in the research. This phase was also initiated with the evaluation of the focus on the different target audiences and marketing the religion. The analysis aimed to identify in what proportion how the farming communities focus on the people not acquainted with the religion yet and categorizing the types of information the rural communities communicate to the public. Following this, the main focus was on how the rural communities seek to attract people towards Krishna Consciousness and whether there are any similarities or differences in the practices of the rural communities of the different countries. This meant identifying the bundles of products and services and the overall experiences the farming communities offer to those arriving for a visit; with special focus on the different courses, festivals and any kind of events.

The content analysis was followed by field research observations in the farming communities examined in order to clarify and confirm the findings of the content analysis. This meant a personal visit of 1-2 days in each community at a pre-arranged time. Some communities provided a person responsible for guiding the visit, while in other cases the observations were carried out without any guidance. The observations were unstructured and took place between June 2017 and July 2019. Since Krisna Völgy in Hungary is the community of the largest population and most diverse set of portfolio and marketing activities in Europe, this entity was set as a benchmark for studying other villages.

During the field research the main goal was to observe and identify the most important characteristics, which make the countries with farming communities stand out in Europe and to find similarities or differences in their activities compared to the countries without rural entities. The communities were analyzed along the marketing mix of services marketing (7P), aiming to identify the similarities and differences in marketing services and religions, while also highlighting the most important shortcomings of the model in the case of religious communities. Each element of the 7Ps were analyzed and evaluated separately, then the rural communities were compared in order to find the patterns in the practices of Krishna-conscious farming communities. Since - as the literature analyzed suggested - many of the elements of the marketing mix are bound by the fundamentals of the religion, special emphasis was put on how the devotees of Krishna Consciousness overcome these problems, how the different elements of the marketing mix are altered to serve the purpose better. The work was initiated by the analysis of the product itself and the elements of the marketing mix, which were subject to the most modification - price, place and promotion -, then followed by those of minor changes (people, processes, physical evidences). Notes were taken of each rural community and their most important characteristics, including facilities and programs offered and marketing tools applied and the data collected through observation were summarized in a database.

Following the content analysis and the data collection of the field research observations, the molecular model - created by SHOSTACK (1977) and applied by SRINIVASAN (2012) - was used to evaluate and summarize the most important characteristics of each country. Shostack and Srinivasan created the molecular model to analyze the offers created by service providers in details by visualizing the good and service elements of certain offers, which may own both tangible and intangible characteristics. The molecular model is applicable to visualize and analyze complex service offers, which besides the core service - may contain a set of tangible and intangible elements. Molecular models usually mark tangible and intangible parts by different colors or lines in order to show clearly, whether a certain service offer is more based on tangible or intangible elements. This research applies an altered molecular model (based on the original work of Shostack) in order to distinguish and visualize the different elements of appearances of Krishna Consciousness in certain countries, regardless of tangibility. The aim of the modified molecular model is to identify those institutions and activities, which contribute to spreading the knowledge about the religion in a certain country. In these molecular models the core product is not a service, but always the religion marked in grey color, while the institutions operated by the religion in the country and other activities - just like the tangible and 
intangible elements of the original molecular model - are grouped around them. The model does not interpret the weight of the different institutions and activities, therefore the sizes of the circles do not carry any meaning, they solely serve the purpose of better separability. Since they are the focal point of the research, farming and rural communities are marked with grey color and bold circles; and their offers and activities are grouped around them. This analysis of the institutions and activities shows the fields on which the different countries are the most active; and the visualization makes comparisons and finding patterns easier. After creating the molecular model for each country separately, the aggregated model of Krishnaconscious communities of Europe was created (SHOSTACK, 1977; SRINIVASAN, 2012).

In order to confirm and clarify the results of the observations and to receive more detailed information on the operation of the communities, in-depth interviews were carried out at each location. The interviews closely followed the observations, as both happened during the same visit, therefore the observations did not have such a huge influence on the original draft of the interviews, however, in all cases necessary modifications and additions were included. The only exception was Krisna Völgy in Hungary, where multiple visits were possible due to its geographical proximity, which further strengthened the benchmark role of this community. In this case it was possible to separate the time of the observations and the in-depth interviews, therefore the experiences in Krisna Völgy supported the formation of the draft of the interview as well. The interview questions discussed were structured around six main areas: general information, selfsufficiency and production, external relations, marketing activities, future plans and vision.

Twenty three interviews were carried out in the seven communities, focusing on respondents, who are involved in the fields of marketing, tourism or guest management. In the case of larger entities these roles were usually clearly separated, while it was characteristic of the smaller ones to have these combined, or not to have a person dedicated to these areas at all. In these cases the respondents were chosen based on having been a member of the community long enough to have an overview of the operations.

\section{RESULTS AND DISCUSSION}

After carefully analyzing the methods devotees use to promote the religion, it became clear that some things have not changed in the past decades: the traditional way of promoting Krishna Consciousness has always been talking to people on the streets and selling books, ever since the appearance of the religion in the Western World in the 1960's (KAMARÁS, 1998; WUAKU, 2012). These methods are still visible nowadays, and they could be found in all the countries examined. However, marketing and technology have developed a lot in the past fifty years, and people devoted to Krishna consciously apply numerous new methods in order to fulfill the most important goal set by their spiritual leaders: to spread the teachings of Krishna.
The content analysis of the central websites of the religion had shown that we can distinguish different types of institutions, which are responsible for the majority of the marketing activities related to Krishna Consciousness in Europe. The most comprehensive information on the communities of Europe was provided by the official website of the International Society for Krishna Consciousness (ISKCON) and ISKCON Desire Tree, the official multimedia social network of the religion, where all the institutions related to Krishna Consciousness are registered. The content analysis of the two sites has shown that the Krishna-conscious institutions all over the world - and also in Europe - may be categorized into four main types, which are

- temples or centers,

- rural or farming communities,

- educational centers,

- restaurants (ISKCON, 2019, ISKCON Desire Tree, 2019).

These labels provided the basis for the further analysis, where the presence of the religion in the European countries was examined, considering the number and variety of the Krishna-conscious institutions existing within their borders.

The institutions of largest density were the temples and centers, 178 of them may be found in various European countries, while there are only 37 restaurants, 18 farming or rural communities and just five educational institutions. The countries with the most institutions were Russia (33), Ukraine (25), the United Kingdom (24) and the Netherlands (12) and Germany (12). In all of these countries temples and centers were the most frequent forms of appearance, but there are farming and rural communities in Ukraine and Germany and restaurants in Russia. The country with the most diverse set of institutions was the United Kingdom, where besides the 16 centers and temples one rural community, two educational institutions and four restaurants may also be found.

The content analysis of the online presence of the religion in the different countries has shown that most of the national communities are using at least one online platform, most often they operate a website, or Facebook page on behalf of the Krishna-conscious society in the country. However, on the national sites they focus mainly on communicating to devotees and not to the wider public. In some countries central sources of religious communication and promotion are missing, but temples and centers usually have a website and/or a Facebook page, similarly focusing mostly on withincommunity communication; besides a general description they focus on community news, upcoming events and religious contents.

Restaurants put the emphasis (obviously) on vegan offers and catering, not so much on religion. Their websites and social media sites are built similarly to those of non-religion-bound restaurants, focusing on the menu, daily offers, bookings and other practical information, while religion appears only among the general information. Restaurants target their messages on those, who already follow a vegan diet - regardless of religious beliefs - therefore are to a certain extent already involved in a lifestyle similar to devotees of Krishna Consciousness. 
Table 1. introduces the most important characteristics of the seven communities, which agreed to participate in the research and where the field research observations took place.

Table 1. Core information of the communities visited during the qualitative research phase

\begin{tabular}{|c|c|c|c|c|c|}
\hline Village & Country & Founded & Population & $\begin{array}{l}\text { Main } \\
\text { profile }\end{array}$ & $\begin{array}{l}\text { Facilities } \\
\text { available }\end{array}$ \\
\hline $\begin{array}{l}\text { Krisna } \\
\text { Völgy }\end{array}$ & HUN & 1993 & 131 & $\begin{array}{l}\text { Tourism } \\
\text { and } \\
\text { organic } \\
\text { products }\end{array}$ & $\begin{array}{l}\text { Temple } \\
\text { Restaurant } \\
\text { Guest house } \\
\text { Gift shop } \\
\text { School } \\
\text { Cowshed center } \\
\text { Bio garden } \\
\text { Apiary }\end{array}$ \\
\hline
\end{tabular}

\begin{tabular}{|c|c|c|c|c|c|}
\hline Radhadesh & BEL & 1980 & 120 & $\begin{array}{l}\text { Tourism } \\
\text { and } \\
\text { cuisine }\end{array}$ & $\begin{array}{l}\text { Temple } \\
\text { Restaurant } \\
\text { Guest house } \\
\text { Gift shop } \\
\text { Bakery } \\
\text { Museum } \\
\text { Bookshop } \\
\text { University }\end{array}$ \\
\hline
\end{tabular}

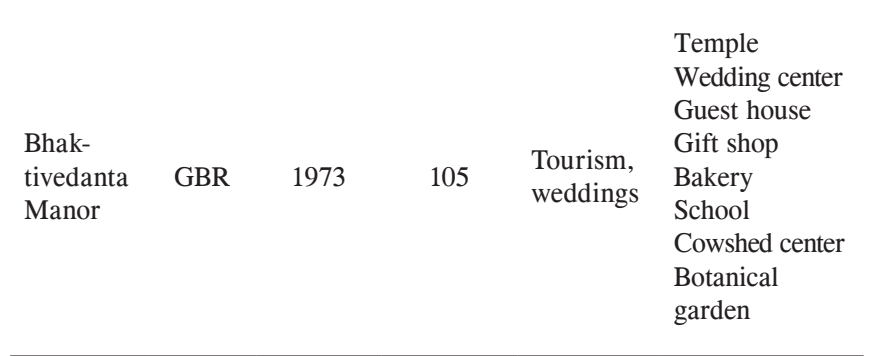

\begin{tabular}{llllll}
\hline & & & & & \\
& & & & Temple \\
Almwiks & & & & Temple shop \\
Gard & SWE & 1981 & 55 & $\begin{array}{l}\text { Yoga } \\
\text { retreats }\end{array}$ & Guest house \\
& & & & Bakery \\
& & & & Farm store \\
& & & & \\
\hline
\end{tabular}

\begin{tabular}{|c|c|c|c|c|c|}
\hline $\begin{array}{l}\text { Krisnuv } \\
\text { Dvur }\end{array}$ & $\mathrm{CZE}$ & 1990 & 33 & $\begin{array}{l}\text { Flour and } \\
\text { biscuit } \\
\text { produc- } \\
\text { tion }\end{array}$ & $\begin{array}{l}\text { Temple } \\
\text { Flour-mill } \\
\text { Apiary } \\
\text { Cowshed center }\end{array}$ \\
\hline
\end{tabular}

\begin{tabular}{|c|c|c|c|c|c|}
\hline $\begin{array}{l}\text { Sim- } \\
\text { hachalam }\end{array}$ & GER & 1980 & 30 & $\begin{array}{l}\text { Guest } \\
\text { house }\end{array}$ & $\begin{array}{l}\text { Temple } \\
\text { Restaurant } \\
\text { Gift shop } \\
\text { Guest House } \\
\text { Cowshed center }\end{array}$ \\
\hline
\end{tabular}

\begin{tabular}{|c|c|c|c|c|c|}
\hline $\begin{array}{l}\text { Goloka } \\
\text { Dhama }\end{array}$ & GER & 1998 & 30 & $\begin{array}{l}\text { Volun- } \\
\text { teers }\end{array}$ & $\begin{array}{l}\text { Temple } \\
\text { Restaurant } \\
\text { Gift shop } \\
\text { Guest House }\end{array}$ \\
\hline
\end{tabular}

Source: own edition based on the field researches and interview
Educational centers - especially universities - are visibly focusing a little more on attracting on people from outside the Krishna-conscious population, but due to the nature of their offers they also target those, who already own at least fundamental knowledge concerning the religion or yoga, which is also connected to a certain set of beliefs. However, at the moment these institutions are present in only three European countries.

The most enhanced marketing activities targeting people not involved in Krishna Consciousness may be observed in those countries, where farming or rural communities are present. These institutions generally put a larger emphasis on attracting and involving people from outside the religious community, therefore the countries, where rural communities exist became the focal point of the further research from religious marketing perspective.

When analyzing the marketing activities of the Krishnaconscious communities in Europe, three categories could be identified, where the most important distinguishing factor was the existence of farming communities. The existence of these institutions made visible difference in the marketing activities of the religion towards the society outside Krishna Consciousness.

In the countries where no farming communities exist, Krishna-conscious communities are moderately active in terms of marketing and usually rely on the traditional forms of spreading religion, such as proselytizing and selling books on the streets. Charitable activities are also a traditional element of the activities of the community, which are present in all the countries examined; however, they are important primarily from PR perspective, their aim is not promoting the religion but fulfilling the duties set by the fundamentals of the religion. The lower section of Figure 1 shows the forms of institutions and means of promotion, which exist in most of the countries regardless of the presence of rural communities. Activities on the streets and charity are present in practically every country, which, according to the findings of the in-depth interviews they are still probably the most important form of making contact with people outside the religion; while most of the countries host at least one temple or center as well to serve those already involved. Govinda restaurants are less frequent in the countries without farming communities; and even where they exist, they focus their communication on people already following a vegetarian or vegan diet; and less on the religious aspects, which usually appear on their websites in the form of a short introduction. Some countries operate a national website or social media page, while others rely on the online platforms managed by the temples and centers, but in both cases the communication focuses mainly on existing devotees and members of the community and provide only general information for visitors outside the religion. In those locations, where farming communities exist, we may observe visibly more external communication, which is generally initiated and managed by the rural communities. On Figure 1 can see that there are a large number of additional institutions and activities, which are centered around the farming communities. 
Figure 1 Molecular model of marketing Krishna Consciousness in the countries with farming communities (Own edition)

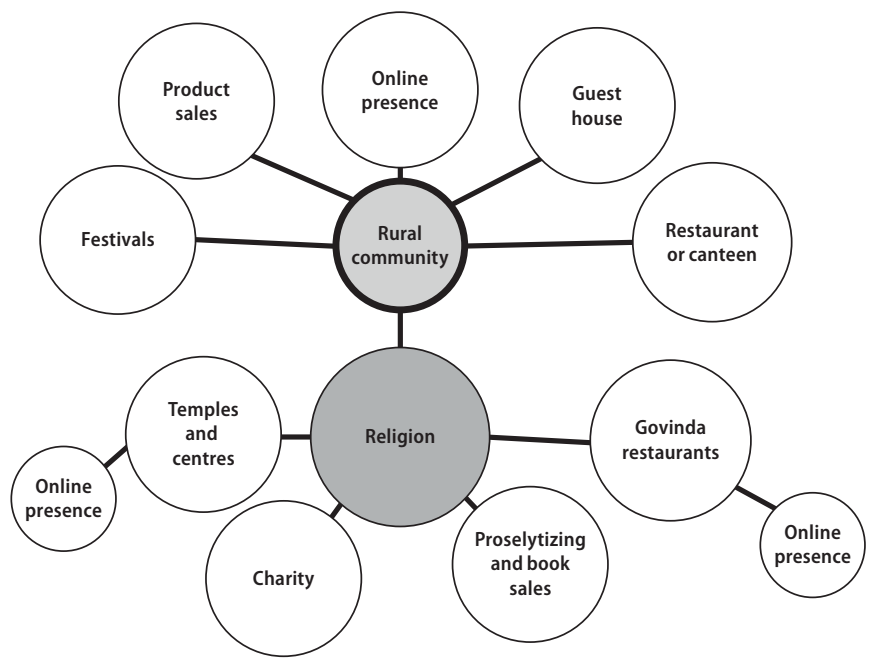

This phenomenon could be observed in the case of all farming communities participating in the research, however, even among the countries with rural communities there are significant differences in terms of the level of activity. Krisna Völgy (HUN), Radhadesh (BEL) and Bhaktivedanta Manor (GBR), which - as Table 1 shows - are the settlements of significantly larger population show enhanced marketing activities, while the activeness of Almviks Gard (SWE), Krisnuv Dvur (CZE), Simhachalam (GER) and Goloka Dhama (GER), which rural communities have approximately one third of the population than the ones mentioned above is moderate.

\section{Farming communities of enhanced marketing activities}

The farming communities of Hungary, Belgium and the United Kingdom are the largest in terms of population in whole Europe with approximately 100 inhabitants each. These entities share numerous characteristics from marketing and management perspective. Krisna Völgy, Radhadesh and Bhaktivedanta Manor are all farming communities wellprepared for visitors, offering a number of facilities, such as guest house, restaurant and one or more shops selling religious items, gifts and tokens, books and vegan treats and spices among others. These facilities enable tourists to enjoy thorough services in case of both one-day and longer, overnight stays in the farming community. Visitor parking lots are available and suitable to host a huge number of people at a time - and signposts direct people towards the most important buildings. In all the three rural communities a reception is operated to welcome and guide the arriving guests, providing information in multiple languages In Krisna Völgy and Radhadesh guided tours are also available, where guests receive information about the history of the area, the life of the inhabitants and the essence of the religion including core values, culture, lifestyle and cuisine. The farming communities offer a wide range of programs as well: each of them organize at least one huge and numerous smaller festivals throughout the year, following the festive calendar of Krishna Consciousness. According to the interviewees these events attract hundreds of visitors each - though exact statistical data are missing in most cases -, and not only people devoted to Krishna Consciousness, but also a significant number of tourists. All the larger rural communities organize camps and workshops related to yoga, cuisine or self-development and various further topics; sometimes jointly with the Bhaktivedanta Universities of their country. In Belgium The Museum of Sacred Arts is ran by the Radhadesh community, which hosts a set of sacred paintings and artworks; Bhaktivedanta Manor of the United Kingdom nurtures ornamental gardens to support peaceful retreats, while the Hungarian rural community has put great efforts in building a sustainable bio-garden, which serves as a model farm and holds a set of educational programs on sustainability. All the three farming communities cooperate with schools on a local and national level too, supporting educational tourism concerning a set of available topics concerning sustainability.

Roughly 20-30000 visitors arrive in a year to each of the rural communities, most of them not devotees, but tourists and people interested in the religion or the Indian culture. The interviews with the management of the rural communities have confirmed that in most of the cases the main motive for visiting the farming communities is not religious, but rather cultural: people are simply driven by curiosity of something unknown, interested in Eastern cultures, vegetarian or vegan cuisine, sustainable practices, yoga or just seeking for a cultural program nearby on their holidays. Devotees have explained that opening up the gates for the public was not intentional in the beginning, but as the interest had risen, they have adapted to the demand, which resulted in increasing consciousness about tourism and the development of nowadays' facilities to be able to fulfil the needs of visitors.

The initial eventuality of tourism has turned into conscious planning and strategy in terms of guest management and marketing; nowadays all three farming communities have well-established departments for guest management, event management and marketing and communication. The aim of these units is to attract people from outside the religious community to visit the farming communities and provide them with an excellent touristic experience. The visitor departments of the rural communities cooperate with local and national tourist offices and are present in numerous tourism-related locations and sights nearby with flyers and posters. Krisna Völgy in Hungary operates a loyalty card system as well, cooperating with tourist attractions in the area, providing discounts and certain benefits for card holders, by which they aim to foster loyalty and increase the number of returning visitors.

All three rural communities put a huge emphasis on online marketing, which, according to the interviewees is one of their most powerful tools of attracting new visitors. The management of the farming communities are of the opinion that religious communities should keep up with technological progress and should utilize the possibilities provided by the internet to increase their recognition. All of them operate informative, up-to-date websites in their native language and English at least, but in some cases in other languages as 
well, and their main focus is again on visitors and tourism. The three sites are built along the similar principles: they promote the farming communities as places worth visiting, offering a wide range of opportunities, while the religious aspect appears mainly in the introduction; and on a separate tab summarizing the history of the religion and its most important characteristics. Contact information, overnight stays in the quest house, restaurant and catering, festivals and other upcoming events however all received separate tabs in the menu to show potential tourists all the available opportunities for their visits. The overall impression of the websites highly resembles those of any touristic attraction, regardless of religious ties, focusing on customer experience.

The social media presence of the three entities is slightly different, however, there are numerous common features in their strategies. All three rural communities have an active Facebook page operated both in their native language and English, where they put a huge emphasis on their events and festivals, including pre-event promotion, active visual broadcast of images and videos during the whole duration and post-event follow-up. Among the three destinations Krisna Völgy is the most active in terms of events, they organize numerous workshops and camps besides the festivals as well. Apart from events, the contents of the three pages are diverse: Krisna Völgy puts the most emphasis on tourism by promoting free-time activities and introducing visitor experience, while there is a strong presence of public education in terms of social responsibility and sustainability. Bhaktivedanta Manor posts frequently of the core values of Krishna Consciousness, while Radhadesh takes the golden mean by combining the touristic and the religious aspect.

All of the rural communities are active on Instagram as well, and again, Krisna Völgy focuses more on the sights and the touristic aspects, while Radhadesh and Bhaktivedanta Manor more on the community life and the religion by posting more about the interiors of the temple and the life of devotees.

YouTube is the platform where the largest differences may be observed among the three entities examined. The channel of Krisna Völgy exists under the umbrella-channel of Krisna. $\mathrm{hu}$, the national YouTube channel together with numerous other thematic channels on topics such as sustainability, cuisine of religious values. Their focus is again on tourism by offering short virtual tours and broadcasting about festivals and workshops; but the introduction of the religion appears as well in the form of videos introducing different ceremonies and traditions. Radhadesh maintains a channel only for Radhadesh Mellows, one of their main music festivals; here the focus is on the performers and broadcasting about the event. The channel contains video and audio materials of the festivals and the artists. Bhaktivedanta Manor focuses solely on religion on this platform by broadcasting religious ceremonies and speeches of their spiritual leaders happening in their temple.

Certainly, the rural communities do not only apply online marketing tools to promote the visiting opportunities, however, as the interviewees responsible for marketing have clarified, besides personal relationships with the people outside the community and targeting them through proselytizing activities on the streets, at the moment the online communication forms are the ones they can rely on the most. Fliers are available at the receptions of the three farming communities promoting certain events, courses or workshops, but they are placed only in a few tourist offices and frequently visited locations in the close proximity of the rural communities. Posters are also applied only in a geographical area with a radius of approximately 50 kilometers; and they are placed only seasonally, mainly just to promote the largest festivals of the year.

The interviewees emphasized that PR activities are also highly important in the life of all three rural communities; especially as Krishna Consciousness is a new religious movement striving for recognition and acceptance in Europe. The rural communities pay a lot of attention to the information published about them in the media; working with reporters and television crews to educate the public about the religion. An important part of the PR activities are charitable initiatives, which are usually either fostered by the national Krishna-conscious organization or carried out jointly with other churches or charity groups.

Numerous researchers have suggested the usage of the $7 \mathrm{P}$, the marketing mix of services marketing to analyze the marketing activities of religious groups, while others have raised the attention to the shortcomings of the model, which do not make it entirely suitable for the purpose (CHEN, 2011; JURAVLE et al., 2016; MULYANEGARA et al., 2010;). One of the main concerns was that the majority of the elements of the marketing mix are predetermined by the fundamentals of the religion; therefore marketers of religious communities may only have freedom in the field of promotion, which is also limited due to the presence of negative attitude towards the idea of marketing religions (ANN and DEVLIN, 2000; MULYANEGARA et al., 2010; MCGRAW et al., 2011).

Analyzing the largest Krishna-conscious farming communities in Europe we can see that they have solved both challenges by transforming the product from religion to tourism. This shift has put the tourist attraction in the focal point of the marketing mix instead of religion, which is an area, where the 7Ps of service marketing are commonly applied (AMINBEIDOKHTI, 2010; MENDOZA VARGAS et al., 2019; SHEIKHI and PAZOKI, 2019). Shifting the product to the area of tourism has created larger freedom in altering the elements of the marketing mix: on the touristic level religious communities may add certain elements to create a complex touristic product, which suits the needs of the customers without harming the fundamentals of the religion and they can set the other elements of the marketing mix to reach the audience the most efficiently. As seen before, promotion has received a clearly touristic focus by cooperating with tourism offices and enhancing the visitor experience on the online platforms.

During the interviews it became clear that the most important aim of the touristic attractions is to make people acquainted with the religion, to create a place where they can get involved without preconceptions or prejudices, and all the 
elements of the marketing mix - analyzed in the following serve this purpose as well. Former locations of meeting the religion, such as temples and gathering points were less known by non-devotees, therefore did not attract new community members. Stepping on the field of tourism, Krishna-conscious communities became more visible to non-members as well.

A large shift caused by the creation of the touristic product happened in terms of price. As discussed before, price of religious products may be interpreted in non-financial terms in most cases; and in the case of Krishna Consciousness it means significant changes in lifestyle, such as forgoing of eating meat, consuming caffeine or alcohol, while taking the habit of chanting the Hare Krishna mantra, doing services for Krishna and being exposed to stereotypes by the public. These are usually perceived as a high price for joining the community, which, according to the interviewees prevents many people from getting to know the religion at all. By creating the touristic product this barrier has decreased significantly, since people take no obligations by simply visiting an attraction. 'Earlier there was a lot of skepticism and refusal; some people even refused to come inside the community.' - explained a guest manager - 'As our reputation as a tourist attraction has grown, we experience more openness and curiosity from our visitors.' This way the only non-financial cost visitors are going to face is the opportunity cost of not choosing another place to spend their free time.

On the other hand, price in financial terms has appeared by the introduction of the touristic product. In Krisna Völgy there is an overall entry fee for the grounds - with special prices for the festivals -, and in Radhadesh visitors pay for the guided tours and the entry to the museum. Visiting Bhaktivedanta Manor and the meals there are free, but guests are charged for overnight stays in all three places. In Krisna Völgy and Radhadesh there are restaurants to serve the guests, where they receive professional service from the devotees in return for their payment. All the three farming communities operate at least a small shop of gifts and religious items, in Krisna Völgy there is a store of organic products produced by the devotees, while in Bhaktivedanta Manor and Radhadesh bakeries are operated as well and the latter has a bookstore too. The products sold should naturally be paid by the customers, but often these prices are labelled as donations to the community.

'We do not operate our village to gain profit' - explained a tour guide - 'We regard the entry fees and the prices paid for our products as donations for the village and for our deities - even if our visitors don't know it. The money received is invested in our facilities, and as long as people see this and don't perceive us to become profit-oriented, there is almost no negative feedback on us asking for money for certain things.'

One respondent mentioned financials to be a sensitive topic, but generally most of the interviewees shared the opinion that as long as they do not go for profit, visitors generally accept having to pay for the services. 'We need to pay our bills too, and people accept this.' - summarized one of them briefly.
In the rural communities people living there dress according to the Indian traditions and they do services for the community, which include daily maintenance tasks, but due to the touristic product also guiding the guests or preparing food in the kitchens for them. Their actions and attitude represent the behaviors required from the devotees by the principles of the religion. Certainly, this does not only serve marketing purposes, but usually the requirements are strict on who may live and work in these locations, which makes sure of a clear image of people devoted to Krishna Consciousness.

Rituals and different processes are also determined mainly by religious requirements, however, also in this case the touristic product has made it possible - and necessary - to apply some changes. Tasks, such as welcoming guests, tour guiding or organizing mass catering became daily duties of the devotees; many of the religious rituals were opened up to the public and sacred festivities became well-promoted festivals hosting hundreds of tourists. Most of the processes have not changed in their essence, but became public, while numerous extra duties occurred to serve the needs of the tourists. Many of the managers have admitted that these practices put a lot of extra burden on the inhabitants of the rural communities; however, most of the devotees regard this - just like selling books on the streets - as part of their service to their deity.

Physical evidences, such as temple buildings and the setup of the rural communities vary by country; but the interiors usually show similar characteristics, exhibiting the traditional motives and colors of Indian Krishna-temples and hosting a statue of A. C. Bhaktivedanta Swami Prabhupada, the person who has spread the religion in the Western world. The altars of the temple rooms give home to one or more deities; and this is the central location, the heart of each temple. On the other hand there is not such uniformity in the external design of the temples and community buildings in the different countries. In Krisna Völgy the temple and the central buildings follow the Indian style of architecture, but the houses of the devotees are built along the local traditions. Radhadesh is located in a Belgian castle, while Bhaktivedanta Manor in a traditional English manor house. These adaptations were necessary for financial and practical reasons; however, some other physical elements were created clearly for the convenience of tourists. All three farming communities operate a guest house, usually with highest level of convenience than the places where the devotees live and they also operate restaurants and buffets of professional service, while devotees usually eat in their houses, or sitting on the floor in the temple room. Exhibitions, parking lots and shops are all operated for touristic purposes, to provide the best possible visitor experience.

'We do not need these facilities. We don't even need the temple to practice our religion; the main purpose of the whole settlement is to be able to be able to fulfill our duty and attract people to get to know us.' - explained a manager.

Table 2 summarizes the most important elements of the marketing mix of the three farming communities of enhanced marketing activities. In the table we can see that most of the differences are present among the first four elements of the marketing mix - product, price, place and promotion - since 
these are the elements, in which the management of the rural communities have the most freedom thanks to the touristic product. The last three elements - people, processes and physical evidence - are more uniform, since there are more determined by the fundamentals of the religion.

Table 2. Marketing mix of the farming communities of enhanced marketing activities (own edition)

\begin{tabular}{|c|c|c|c|}
\hline & $\begin{array}{l}\text { Krisna Völgy } \\
\text { (HUN) }\end{array}$ & $\begin{array}{l}\text { Radhadesh } \\
\text { (BEL) }\end{array}$ & $\begin{array}{l}\text { Bhaktivedanta } \\
\text { Manor (GBR) }\end{array}$ \\
\hline & \multicolumn{3}{|c|}{$\begin{array}{l}\text { Complex touristic product } \\
\text { Temple } \\
\text { Guest house } \\
\text { Gift shop } \\
\text { Festivals } \\
\text { Workshops }\end{array}$} \\
\hline Product & $\begin{array}{l}\text { Restaurant } \\
\text { School } \\
\text { Cowshed center } \\
\text { Bio garden } \\
\text { Apiary } \\
\text { Camps }\end{array}$ & $\begin{array}{l}\text { Restaurant } \\
\text { Bakery } \\
\text { Museum } \\
\text { Bookshop } \\
\text { University } \\
\text { Camps }\end{array}$ & $\begin{array}{l}\text { Wedding } \\
\text { center } \\
\text { Bakery } \\
\text { School } \\
\text { Cowshed } \\
\text { center } \\
\text { Botanical } \\
\text { garden }\end{array}$ \\
\hline
\end{tabular}

\begin{tabular}{cc}
\hline & Online marketing \\
Website & Facebook \\
Instagram \\
Yromotion & YouTube \\
& Fliers \\
Posters \\
PR activities \\
Newspapers \\
Television \\
\hline
\end{tabular}

\begin{tabular}{ll}
\hline Opportunity cost \\
Guest house prices \\
Prices of workshops \\
Product prices
\end{tabular}

Price

$\begin{array}{ll}\text { Entry fee to visit } & \text { Fee of the guided } \\ \text { Entry fee for } & \text { tour } \\ \text { festivals } & \text { Museum entry fee } \\ \text { Meal prices } & \text { Meal prices }\end{array}$

Following the principles of Krishna Consciousness Aiming to transmit the knowledge about their religion

People Fulfilling tourism-related duties

Working for highest possible customer experience

Rituals guided by religious principles BUT made open for the public

Reception services

Processes

$$
\text { Guest house booking }
$$

Official vegan catering

Guided tours Guided tours

Additional facilities to fulfil customer needs

\begin{tabular}{llll}
\cline { 2 - 3 } Physical Evidence & $\begin{array}{l}\text { Following } \\
\text { Indian traditions }\end{array}$ & $\begin{array}{l}\text { Following Indian } \\
\text { traditions BUT } \\
\text { adapting to local } \\
\text { culture }\end{array}$ & $\begin{array}{l}\text { Following } \\
\text { Indian tradi- } \\
\text { tions BUT } \\
\text { adapting to } \\
\text { local culture }\end{array}$ \\
& & \\
\hline
\end{tabular}

\section{Communities of moderate marketing activities}

In those countries, where the rural communities are less developed - and of smaller population -, the product is decisively still religious, with certain touristic elements, which means that the touristic product is visibly less complex than in the farming communities discussed above. In Almviks Gard (SWE), Krisnuv Dvur (CZE), Simhachalam (GER) and Goloka Dhama (GER) temples are present as well and ceremonies are open to the visitors, but these rural communities are not prepared to host such a huge number of visitors as the larger ones. There are no receptions to provide guidance to the visitors, parking lots are small and only a few signposts indicate the most important buildings of the farming community. Three of the four smaller farming communities provide the opportunity for overnight stays, but their guest houses are smaller, or sometimes not even houses, but only dedicated parts of the temple building. For overnight visitors Goloka Dhama offers a set of nearby guest houses instead of staying within the community. In these rural communities there are not always separate restaurants for visitors either, but the opportunity is offered to eat together with the devotees in the canteen. In the smaller rural communities there are no official shops, but they also sell a selection of books and religious items in the temple shops, which are open upon request. Almviks Gard is the only one of the four communities, where a bakery and a farm store may also be found, but they operate only with limited opening times. All four of the farming communities organize one or more festivals throughout the year, which usually attract 100-200 visitors, but to be able to serve this many people at the same time, all of them need to use tents or cooperate with the villages nearby.

To these, smaller farming communities there are only a maximum of 2-3000 guests arriving in a year and according to the experiences of the managers a significant proportion of them are devotees, or followers of other religions originating from India. In their case the motives for visiting are decisively religious; which means that smaller rural communities do not rely so much on tourism at the moment, however the leaders of all the three entities expressed their wish to follow the path of their Hungarian, Belgian and British fellow communities. In each of the smaller farming communities examined, Krisna Völgy, Radhadesh and Bhaktivedanta Manor are regarded as role models, but these entities are missing a number of necessary assets to step on the path of progress.

'To achieve this level of development there is a need for a leader with a vision and financial resources' -explained a guest house manager - 'And to be able to serve this many people suitable infrastructure is crucial as well. We have our plans, but it takes time and money to realize them.' According to the experiences of the respondents the cooperation between the farming communities of the different countries is strong; which fosters the exchange of experiences and best practices among larger and smaller entities.

Since smaller farming communities are less able to serve a large number of visitors, their activity in terms of touristic promotion is significantly lower too. All the four smaller 
farming communities operate a website too, but the one of Krisnuv Dvur is currently available in Czech language only, while the others in their native language and English too. There are differences in the structure of the websites as well: Almviks Gard puts the greatest emphasis on visitors on their website, providing detailed information on visitors' opportunities and a contact form. 'Visit' menu also appears on the websites of Simhachalam and Krisnuv Dvur (though on the latter only in Czech), but it is missing from the website of Goloka Dhama, where only a list of guest houses and directions are indicated. Festivals however are an important focal point in all four cases; and the interviews have confirmed that from touristic point of view these events are the most important attractions of the smaller rural communities currently. However, compared to the larger farming communities, on the websites of smaller rural entities the emphasis of religious information is greater.

The same is true for the social media activities for all the four smaller rural communities: on Facebook the focal points are religiously-themed posts and festivals; the only exceptions are Krisnuv Dvur, where farming - the main profile of the community - receives a role as well, and Simhachalam, where the daily life of the community is also introduced. Goloka Dhama and Krisnuv Dvur are also present on Instagram, but the German community shares only religiously-themed posts, mainly of their deities, while the account of Krisnuv Dvur has less than ten posts, focusing on religion and farming. All four of the smaller rural communities own YouTube channels, but here without exception, the main focus is on the religion: Simhachalam broadcasts some of their rituals online, while the other three communities post videos of their devotees talking about religiously related topics, playing traditional music; and less frequently also about the life within the community and festivals.

Fliers are rare in the smaller rural communities, but similarly to the larger entities, they mainly promote festivals and courses available in the farming communities. However, they are placed only in the temple buildings and sometimes in the nearest settlement, but the number of people they reach is low. Posters are placed also in the nearby settlements to promote festivals, similarly to the practices of larger farming communities.

PR activities appear in the smaller rural communities too, but in significantly smaller volume than in the case of the larger farming communities. The cooperation with media is mostly occasional and even though charity events and activities are organized, their publicity is also low.

All the interviewees of the smaller rural communities agreed that it would be early for them to cooperate with tourism agencies, as currently they are not able to cope with greater number of tourists; this implies that the creation of a place for tourists to meet the religion has not fully happened yet; and the lack of the complex touristic product influences all the elements of the marketing mix as well.

As the touristic product is limited, significant shifts in price have not happened either, which prevents the positive effects of the product shift to take place. People may buy meals or stay overnight in the guest house for a certain amount of money, items may be purchased as well, but the openness, which could be observed in the case of larger farming communities is not yet present in the smaller ones. 'Locals have started to be more open towards the community after a while, but many still perceive us as an exclusive sect, which only those may get acquainted with, who share the same principles or are ready to assimilate.' - explained one devotee fulfilling duties of managing external relations.

In Table 3 the elements of the marketing mix of the three farming communities of moderate marketing activities are summarized. In their case the differences in the first four elements are not so significant due to the touristic product not having elaborated yet; and the last three are again mostly uniform and determined by religion. Even though similar promotional tools are used as by the larger entities, the activity of their usage is significantly lower for the smaller farming communities.

Table 3. Marketing mix of the farming communities of moderate marketing activities (own edition)

\begin{tabular}{|c|c|c|c|c|}
\hline & $\begin{array}{l}\text { Almviks Gard } \\
\text { (SWE) }\end{array}$ & $\begin{array}{l}\text { Krisnuv Dvur } \\
\text { (CZE) }\end{array}$ & $\begin{array}{l}\text { Simhachalam } \\
\text { (GER) }\end{array}$ & $\begin{array}{l}\text { Golokha } \\
\text { Dhama } \\
\text { (GER) }\end{array}$ \\
\hline \multirow[b]{2}{*}{ Product } & \multicolumn{4}{|c|}{$\begin{array}{l}\text { Religious product with touristic elements } \\
\text { Temple } \\
\text { Festivals } \\
\text { Workshops }\end{array}$} \\
\hline & $\begin{array}{l}\text { Temple shop } \\
\text { Guest house } \\
\text { Bakery } \\
\text { Farm store }\end{array}$ & $\begin{array}{l}\text { Flour-mill } \\
\text { Apiary } \\
\text { Cowshed } \\
\text { center }\end{array}$ & $\begin{array}{l}\text { Restaurant } \\
\text { Gift shop } \\
\text { Guest House } \\
\text { Cowshed } \\
\text { center }\end{array}$ & $\begin{array}{l}\text { Restaurant } \\
\text { Gift shop } \\
\text { Guest House }\end{array}$ \\
\hline \multicolumn{5}{|c|}{$\begin{array}{l}\text { Online marketing } \\
\text { Website } \\
\text { Facebook } \\
\text { Instagram } \\
\text { YouTube } \\
\text { Fliers } \\
\text { Posters } \\
\text { PR activities } \\
\text { Newspapers } \\
\text { Television }\end{array}$} \\
\hline Place & $\begin{array}{l}\text { Peaceful place } \\
\text { An opportunit }\end{array}$ & $\begin{array}{l}\text { suitable for re } \\
\text { for outsiders }\end{array}$ & $\begin{array}{l}\text { reat } \\
\text { get an insight }\end{array}$ & \\
\hline \multirow[t]{2}{*}{ Price } & \multicolumn{4}{|c|}{$\begin{array}{l}\text { Opportunity cost } \\
\text { Guest house prices } \\
\text { Prices of workshops } \\
\text { Product prices }\end{array}$} \\
\hline & & \multicolumn{3}{|c|}{ Meal prices } \\
\hline People & $\begin{array}{l}\text { Following the } \\
\text { Aiming to trar } \\
\text { Fulfilling tour }\end{array}$ & $\begin{array}{l}\text { rinciples of } \mathrm{K} \\
\text { mit the knowl } \\
\text { m-related duti }\end{array}$ & $\begin{array}{l}\text { ishna Consciou } \\
\text { dge about their } \\
\text { s occasionally }\end{array}$ & $\begin{array}{l}\text { ness } \\
\text { religion }\end{array}$ \\
\hline \multirow[t]{2}{*}{ Processes } & \multicolumn{4}{|c|}{$\begin{array}{l}\text { Rituals guided by religious principles BUT made open for } \\
\text { the public } \\
\text { Opportunity to join in catering }\end{array}$} \\
\hline & $\begin{array}{l}\text { Guest house } \\
\text { booking }\end{array}$ & $\begin{array}{l}\text { Guest room } \\
\text { booking }\end{array}$ & $\begin{array}{l}\text { Guest house } \\
\text { booking }\end{array}$ & \\
\hline \multirow[b]{2}{*}{$\begin{array}{l}\text { Physical } \\
\text { Evidence }\end{array}$} & \multicolumn{4}{|c|}{$\begin{array}{l}\text { Externally - local culture } \\
\text { Internally - Indian markings }\end{array}$} \\
\hline & $\begin{array}{l}\text { Few addition- } \\
\text { al facilities } \\
\text { for guests }\end{array}$ & $\begin{array}{l}\text { Few ad- } \\
\text { ditional } \\
\text { facilities for } \\
\text { guests }\end{array}$ & $\begin{array}{l}\text { Few ad- } \\
\text { ditional } \\
\text { facilities for } \\
\text { guests }\end{array}$ & \\
\hline
\end{tabular}


People dress and behave according to the principles of the religion, but this marketing element remains almost unchanged; only a few inhabitants are prepared to manage guests; and for most of them this is not a part of their daily duties, just an occasional, additional task.

The same is true for the processes of handling visitors: even though opportunities are given to visit the different rituals and buildings, there are no well-established processes, such us guided tours. The only exceptions are the guest houses, as for accommodation there are clear booking processes and personnel dedicated to manage them.

Interestingly, in terms of physical evidence the religious influence is less observable in the case of smaller rural communities: in their cases the buildings generally follow the architectural patterns of the country of location, only the altars, the temple rooms and parts of the interior design follow the Indian traditions. According to the respondents this can be traced back to two important, interrelated factors: financials and the lack of tourism. As the managers of the larger farming communities have explained, many of the physical elements of the entities are created for the sake of tourism; devotees do not need them in daily life. Certainly, this means the lack of larger guest houses, shops and restaurants, but also the simplicity of decorations. Limited tourism does not make these aspects necessary, however, the lack of them also prevents the community from hosting more visitors, which in turn could improve their financial situation and provide an opportunity for investing more in the infrastructure. As mentioned before by the respondents, the way to overcome this challenge would be to have a clear vision and a set of goals within the communities - which is already present in some of them, but missing in others.

\section{CONCLUSIONS}

By comparing farming communities with enhanced and moderate marketing activities we can clearly see the benefits of shifting the product from religion to tourism. Table 4 summarizes the changes the shift from religious to touristic products has caused in terms of the elements of the marketing mix. These changes have happened thoroughly in the farming communities with enhanced marketing activities, as Table 2 has shown, while only some elements of the change have been realized in the rural communities with moderate marketing activities, as Table 3 summarizes, yet their aims include the tendency to move towards more significant shifts in the future as well. The findings of these results are aggregated in Table 4 to show the generally appearing elements in the rural communities analyzed. The in-depth interviews have proved that managers of entities with moderate marketing activities see the opportunities as well and by seeing the examples of an applicable marketing mix they aim to go along the same path in the future.

The factors underlined show the religious influences that have remained in the marketing mix in the case of the touristic product as well. The table shows how the freedom of Krishnaconscious communities has increased in terms of adapting the elements of the marketing mix to reach larger audiences.
Table 4 - The changes in the marketing mix by shifting the product from religion to touristic destination (own edition)

\begin{tabular}{|c|c|c|}
\hline & Religion & Touristic destination \\
\hline Product & $\begin{array}{l}\text { Set of beliefs, afterlife } \\
\text { benefits }\end{array}$ & $\begin{array}{l}\text { Complex cultural } \\
\text { experience }\end{array}$ \\
\hline Price & Lifestyle changes & $\begin{array}{l}\text { Opportunity cost } \\
\text { Entry/tour guiding fee } \\
\text { Meal prices } \\
\text { Guest house prices } \\
\text { Prices of workshops } \\
\text { Product prices }\end{array}$ \\
\hline Place & $\begin{array}{l}\text { Temples and gather- } \\
\text { ing points } \\
\text { Peaceful places suit- } \\
\text { able for retreat }\end{array}$ & $\begin{array}{l}\text { Tourist attraction of } \\
\text { high reputation } \\
\text { The place to get ac- } \\
\text { quainted with Krishna } \\
\text { Consciousness }\end{array}$ \\
\hline Promotion & $\begin{array}{l}\text { Proselytizing on the } \\
\text { streets } \\
\text { Via the rural com- } \\
\text { munities }\end{array}$ & $\begin{array}{l}\text { Online marketing } \\
\text { Tourism agencies } \\
\text { PR }\end{array}$ \\
\hline People & $\begin{array}{l}\text { Behavioral patterns } \\
\text { set by religion } \\
\text { Aiming to transmit the } \\
\text { knowledge about their } \\
\text { religion }\end{array}$ & $\begin{array}{l}\text { Behavioral patterns } \\
\text { set by religion } \\
\text { Aiming to transmit the } \\
\text { knowledge about their } \\
\text { religion } \\
\text { Fulfilling tourism- } \\
\text { implied duties } \\
\text { Ensuring positive } \\
\text { customer experience }\end{array}$ \\
\hline Process & $\begin{array}{l}\text { Rituals guided by } \\
\text { religious principles }\end{array}$ & $\begin{array}{l}\text { Rituals guided by } \\
\text { religious principles } \\
\text { BUT made open for } \\
\text { the public } \\
\text { Additional processes } \\
\text { to fulfil customer } \\
\text { needs }\end{array}$ \\
\hline Physical evidence & $\begin{array}{l}\text { Following Indian } \\
\text { traditions }\end{array}$ & $\begin{array}{l}\text { Following Indian tra- } \\
\text { ditions BUT adapting } \\
\text { to local culture } \\
\text { Additional facilities to } \\
\text { fulfil customer needs }\end{array}$ \\
\hline
\end{tabular}

Table 4 shows how the marketing mix elements were altered in the farming communities, where the shift of the product from religion to tourism was completed. Price, place and promotion have changed completely, by receiving the focus of tourism rather than religion, while people, processes and physical evidences were only slightly modified, maintaining the fundamental characteristics bound to the religion, but being complemented with additional components in order to fulfil the needs of the touristic product. Keeping the traditional elements of these three factors contributes highly to the purpose of the touristic product in educating the visitors about the religion via providing a complex experience.

Since at the moment this research studied only the Krishna-conscious communities of European countries, the observations may be extended to other continents in the future as well; while and inter-religious study may show how the benefits of the altered marketing mix model may be applied by other religious communities too. In the current ongoing research the effects of the altered marketing mix model on consumer behavior are being analyzed. 


\section{ACKNOWLEDGEMENTS}

This research was supported by EFOP-3.6.1-16-2016-00007 „Intelligens szakosodás a Kaposvári Egyetemen” project.

\section{REFERENCES}

Abela, A. V. (2014): Appealing to imagination: Effective and ethical marketing of religion, Journal of Business Research, Vol. 67, pp. 50-58.

Aminbeidokhti, A., Zargar M., Nazari, M. (2010): A strategic marketing mix to tourist industry, Journal of Strategic Management Studies, Vol. 1. Iss. 3, pp. 49-68.

Ann, S., Devlin, J. F. (2000): American and British clergy attitudes towards marketing activities: A comparative study, Service Industries Journal, Vol. 20. Iss. 4., pp. 47-61.

Attaway, J. S., Boles J. S., Singley R. B. (1997): Exploring Consumers' Attitudes toward Advertising by Religious Organizations, Journal of Marketing Management, Vol. 13 (Fall/Winter), pp. 71-83.

Correa, V. S., Vasconcellos Vale, G. M., de Almeida Cruz, M. (2017): Entrepreneurial orientation and religion: the Pastor as an entrepreneur, Revista de Administracao Vol. 52. pp. 330-340. Permanent link to this document: http://dx.doi. org/10.1016/j.rausp.2016.10.005

Crockett, D. (2016): Religion and the marketplace in the United States. Consumption, Markets \& Culture, Vol. 19., Iss. 2., pp. 206-227 Permanent link to this document: DOI: $10.1080 / 10253866.2016 .1144861$

Culliton, J. W. (1958): A marketing analysis of religion: Can businesslike methods improve the "sales” of religion? Business Horizons, Vol I. (Spring, 1958), pp. 85-92.

Einstein, M. (2008): Brands of Faith: Marketing Religion in a Commercial Age, (Media, Religion and Culture), New York: Routledge. ISBN: 0-203-93887-9

Fine, S. H. (1992): Marketing the public sector - Promoting the causes of public and non-profit agencies. Boston: Allyn and Bacon. ISBN-13: 978-1560006107

Hagevi, M. (2017): Religious Change over the Generations in an Extremely Secular Society: The Case of Sweden. Reviev of Religious Research Vol. 59. pp. 499-518 Permanent link to this document: DOI: https://doi.org/10.1007//13644-017-0294-5

Hashim N., Hamzah M. I. (2014): 7P's: A literature review of Islamic marketing and contemporary marketing mix, Procedia - Social and Behavioral Sciences, Vol. 130., pp. 155 - 159.

Iannaccone, L. R. (2012): Extremism and the Economics of Religion, The Economic Record, Vol. 88., Special issue 2012. pp. 110-115.
International Society For Krishna Consciousness (ISKCON) (2019): ISKCON Centres. Retrieved from: http://centres. iskcon.org Access date: 12.05.2019

ISKCON Desire Tree (2019). Retrieved from: http://centres. iskcondesiretree.com Access date: 12.05.2019

Iyer, S., Velu, C., Mumit, A. (2014): Communication and marketing services by religious organizations in India, Journal of Business Research, Vol. 67., pp. 59-67.

Juravle A. I., Sasu, C. \& Spataru, G. C. (2016): Religious Marketing, SEA - Practical Application of Science, Romanian Foundation for Business Intelligence, Editorial Department, Vol. 11, pp. 335-340.

Kamarás, I. (1998): Krisnások Magyarországon. [Krishnabelievers in Hungary] Budapest: Iskolakultúra.

Mendoza Vargas, C. \& Culquita Salazar, S. G. (2019): Factores del marketing mix que tienen mayor relevancia en las agencias de turismo en la ciudad de Cajamarca en el periodo 2016 - 2019. PhD Dissertation, Universidad Privada del Norte.

McDaniel, S. W. (1986): Church Advertising: Views of the Clergy and General Public, Journal of Advertising, Vol. 15 (March), pp. 24-29.

McGraw, A. P., Schwartz, J. A., Tetlock, P. E. (2011): From the commercial to communal: reframing taboo trade-offs in religious and pharmaceutical marketing, Journal of Consumer Research, Vol. 39., pp. 157-173.

Shaw, D., Thomson, J. (2013): Consuming spirituality: the pleasure of uncertainty, European Journal of Marketing, Vol. 47. Iss. $3 / 4$. , pp. 557-573.

Sheikhi, D. \& Pazoki, M. (2019): Assessing and prioritizing the factors affecting rural tourism marketing using the marketing mix model (A case study: Jozan District, Malayer Township), Journal of Rural Research Vol. 8. Iss. 3., pp. 488-501.

Shostack, G. L. (1977): Breaking free from product marketing, The Journal of Marketing, Vol. 41. Iss. 2., pp. 73-80.

Srinivasan, R (2012): Services Marketing - The Indian context, PHI:Learning Private Limited. ISBN 8120325982

Walrath, M. W. (2017): A Firm Entry Approach to Religious Pluralism and Religious Participation, Economics Bulletin, Vol. 37. Iss. 3., pp. 1805-1816.

Wuaku, A. K. (2012): Selling Krishna in Ghana's religious market: proselytising strategies of the Sri Radha Govinda Temple community of Ghana, Journal of Contemporary African Studies, Vol. 30., pp. 335-357. 